учебник: плюсы и минусы // Современный вузовский учебник: проблемы и решения : сборник материалов межвузовского «круглого стола» 19 декабря 2000 г. - Волгоград, 2001. - С. 71-73. 10. Точиліна Т. М. Науково-теоретичні засади створення навчальнометодичного комплексу з курсу загальної фізики для вищих технічних навчальних закладів / Т. М. Точиліна. - К., 2006. - 220 с.

УДК 371.134:821.161.2

Свімлана Кампов

\title{
КОМПЕТЕНТНІСТЬ І САМОСТІЙНІСТЬ У СИСТЕМІ ПІДГОТОВКИ МАЙБУТНЬОГО ВЧИТЕЛЯ
}

Кампов С. П. Компетентність і самостійність у системі підготовки майбутнього вчителя.

У статті з'ясовується сутність педагогічної категорії на основі осмислення, узагальнення й систематизації поглядів сучасних науковців. Подається спроба генезису поняття у психолого-педагогічній літературі. 3'ясовано, що компетентність $\epsilon$ сукупністю властивостей особистості, які забезпечують ефективне, раціональне і творче використання знань i вмінь самостійного розв'язання завдань в умовах професійних ситуацій та інтересах освітнього закладу.

Ключові слова: компетентність, професійна самостійність, учитель, педагогічна освіта, навичка, уміння.

Кампов С. П. Компетентность и самостоятельность в системе подготовки будущего учителя.

В статье на основе систематизации и обобщения научных взглядов известных исследователей сформулировано понятие «компетентность», охарактеризована его сущность в сфере профессиональной подготовки будущих учителей, рассмотрена эволюция внедрения этого понятия в научный аппарат педагогической отрасли. Установлено, что компетентность - это система свойств личности, которые обеспечивают эффективное, рациональное и творческое использование знаний, умений, навыков для самостоятельного решения задач в условиях профессиональных ситуаций и удовлетворения интересов образовательного учреждения.

Ключевые слова: компетентность, профессиональная самостоятельность, учитель, педагогическое образование, умение, навык.

Kampov S. P. Competence and independence in the training of future teachers.

The article reveals the essence of educational category based on comprehension, generalization and systematization of modern scientists' views. The article points the attempt of the concept genesis in the psycho-pedagogical literature. The author stated that the competence is a system of personality traits. These traits provide an effective, efficient and creative usage of knowledge and skills that help to solve the problems independently in professional situations and interests of the educational institution.

Key words: competence, professional independence, teacher, pedagogical education, skills, abilities.

Як засвідчує досвід, зміст сучасної освіти лише частково відповідає запитам сучасного демократичного суспільства України, а відтак, не спрямований на набуття особистостями необхідних знань i умінь для їх повноцінного існування в соціокультурних умовах XXI століття. Одним із ефективних шляхів оновлення змісту 
освіти й узгодження його 3 нинішніми вимогами до випускників освітніх закладів, інтеграцією до європейського і світового освітніх просторів дослідники називають «орієнтацію навчальних програм на набуття ключових компетентностей та на створення ефективних механізмів їх запровадження» [1, с. 13]. До того ж і науковці постійно наголошують на необхідності відмови від знаннєвої парадигми, оскільки безпосередня інформація, не маючи прикладного характеру, втрачає важливість, а відтак, зникає потреба перевантажувати пам'ять знаннями, нині достатньо лише вмінь користуватися ними. Отже, у сучасних соціокультурних умовах процес професійного становлення вчителя неможливий без чіткого визначення системи знань, умінь i навичок, трансформованих у професійні компетентності, що «сприяють особистісному культурному розвитку..., здатності швидко реагувати на запити часу» [там само]. Отже, очевидною є актуальність з'ясування сутності категорії самостійності в контексті поняття компетентності майбутнього вчителя.

Як показує аналіз праць науковців, нині сформульовано концептуальні засади компетентнісно зорієнтованого підходу до навчання (О. Бермус, В. Байденко, Н. Бібік, Б. Гершунський, Е. Зеєр, І. Зимня, І. Зязюн, В. Козирева, В. Краєвський, Н. Кузьміна, А. Маркова, Л. Мітіна, О. Овчарук, О. Пометун, Л. Петровська, М. Розов, О. Савченко, Г. Терещук, А. Хуторський, В. Шапкін). Однак, як свідчить огляд наукових джерел, донині немає чіткого тлумачення та єдиного розуміння значення лексеми «компетентність».

Mema cmammi: з'ясувати сутність педагогічної категорії «компетентність учителя» на основі осмислення, узагальнення і систематизації поглядів вітчизняних і зарубіжних дослідників, визначити генезис запропонованого поняття у психолого-педагогічній літературі.

Варто зазначити, що в інформаційному просторі педагогічної науки постійно 3'являються нові поняття, що є похідними від терміна «компетентність», - це зокрема «компетентнісна модель», «компетентнісний підхід», «компетентнісне середовище», «компетентнісна освіта», «компетентнісне навчання» тощо. Оскільки науковою методологією передбачено вимогу термінологічної однозначності, то доцільним уважаємо формулювання власного визначення категоріального поняття дослідження.

У психолого-педагогічній літературі розроблено різноманітні підходи до розуміння терміна «компетентність». На основі студіювання наукових джерел можемо констатувати, що поняття «компетентність» використовується головним чином у галузі професійної освіти.

Як відомо, поняття «компетентність» і «компетенція» $є$ відповідниками терміна «competency(e)» англійського походження. У словнику німецької мови як іноземної зазначено, що «компетентність»- це здатність до дії, уміння використовувати знання у практичній діяльності. У тлумачному словнику сучасної української мови подано спочатку прикметник «компетентний» (від лат. «competens» (competensis) - належний, відповідний) - правосильний, що має повноваження; який має достатні знання в певній галузі; 3 чим-небудь добре обізнаний; тямущий; який грунтується на знанні; кваліфікований». Відповідно «компетентність» характеризується як властивість за значенням «компетентний». У словнику іншомовних слів термін «компетентність» тлумачиться як: авторитетність, обізнаність; володіння компетенцією. Поняття «компетенція» пояснюється як коло повноважень якогось органу чи посадової особи; проблема, про яку в кого-небудь багато інформації, що дає йому змогу фахово іï розв'язати.

У словнику 3 професійної освіти термін «компетентність» тлумачиться як «сукупність знань і вмінь, необхідних для ефективної професійної діяльності». В 
електронних словниках мережі Інтернет існує визначення компетентності як рівня досягнень індивіда (кандидата, виконавця) у галузі певної компетенції. Компетенція тлумачиться як галузь самостійної діяльності, що має важливе значення для ефективної роботи всієї організації чи установи, у якій індивід (кандидат чи виконавець) повинен виявити певні знання, уміння, навички поведінки, гнучкі здібності й професійноважливі якості особистості. Компетенція - це галузь відповідальності й визначена сфера повноважень.

В аспекті визначення змісту компетентності вчителя вважаємо за доцільне 3'ясувати генезу становлення й розвитку зазначеної категорії. Студіювання наукових праць В. Байденка, Г. Беліцької, Л. Берестової, І. Зимньої, Н. Кузьміної, В. Куніциної, А. Маркової, Дж. Равена, А. Хуторського, Р. Уайта та ін. зумовлює поетапну періодизацію у процесі становлення і розвитку педагогічної категорії «компетентність».

Відповідно до логічних законів розвитку кожен початковий етап становлення будьякого явища характеризується створенням необхідних передумов його появи, удосконалення і запровадження. Відтак, на первинній стадії запровадження поняття «компетентності» до наукової галузі мали бути створені відповідні ефективні передумови. На початковому етапі запровадження категорії «компетентність» до науково-понятійного апарату педагогіки було введено поняття і створено оптимальні умови для розмежування його 3 терміном «компетенція». Першим, хто осмислював компетентність як окремий термін, за твердженням російської дослідниці І. Зимньої, був німецький науковець Хаберман, який використав зазначену категорію як соціологічний термін у контексті теорії мовної комунікації [2]. Цей факт дає можливість трактувати, що на початковому етапі становлення компетентності як наукової категорії мали місце дослідження різних видів компетенції у площині трансформаційної теорії навчання.

Як відомо, з 1973 р. почали публікуватися дослідження американських науковців Дж. Равена й Д. Клелланда. $\mathrm{y}$ дослідженнях Дж. Равена компетентність характеризується єдністю когнітивного, емоційного й вольового аспектів самостійної діяльності, що спрямована на реалізацію ціннісних установок суб'єкта. Так, у 1984 р. науковець сформулював розгорнуте визначення терміна, за яким компетентність складається 3 низки незалежних самостійних компонентів, причому частина складників стосуються когнітивного аспекту, інші- емоційного. На його думку, складники компетентності $є$ взаємозамінними, оскільки становлять собою структурні частини ефективної поведінки [3, с. 253]. Зазначимо також, що автор у своїй праці розглядав компетентності як мотивовані здібності [там само, с. 258]. У зв'язку з цим Дж. Равен виокремив 37 їх різновидів. Вважаємо за доцільне навести лише ті з них, які певною мірою можуть стосуватися компетентності вчителя: чітке розуміння цінностей $\mathrm{i}$ настанов щодо конкретно поставленої мети; уміння контролювати власну фахову діяльність; здатність застосовувати емоції до професійної діяльності; готовність і досвід самоосвіти; пошук і використання зворотного зв' язку; упевненість у собі; самоконтроль; здатність швидко адаптуватися; схильність до роздумів про майбутнє: звичка абстрагувати; увага до проблем, пов'язаних із досягненням визначеної мети; самостійність мислення, оригінальність; готовність до розв'язання складних, дискусійних і полемічних питань; здатність критично мислити; готовність використовувати нові ідеї й інновації для досягнення мети; довіра; здатність обирати оптимальні рішення, покладатися на суб'єктивні оцінки й ризикувати; ставлення до правил як до вказівок бажаних способів поведінки [там само, с. 281-296].

Як бачимо, у запропонованих різновидах компетентності автор використав категорію «самостійність», психологічні якості - відповідальність, упевненість, що визначають сутність компетентнісного підходу. 
Зазначимо, що у площині зазначених досліджень науковці (Н. Кузьміна, А. Маркова, Л. Петровська та ін.) не лише осмислювали сутність компетентностей, розробляли авторські класифікації, але й намагалися реформувати освіту у напрямку формування компетенцій фахівців як кінцевого результату педагогічного процесу. Так, відомо, що з 1986 р. до основи національної системи кваліфікаційних стандартів Великобританії було включено концепцію компетентнісно-орієнтованої освіти. Студіюючи британський підхід до визначення сутності компетентності фахівця, констатуємо, що компетентність - це сукупність професійних кваліфікацій, які визначають здатність працівника виконувати конкретний вид самостійної діяльності на рівні, встановленому державним стандартом, у діапазоні визначених обставин.

Дещо іншим підходом до визначення змісту і структури компетентності фахівця загалом, й учителя зокрема, вважаємо концепцію, сформульовану американськими дослідниками. Структурним компонентом компетентності науковці вважають навички самоорганізації фахівця, що дозволяють йому швидко оцінювати ситуацію та знаходити творчі шляхи розв'язання проблемної задачі. Отже, відповідно до американського підходу у структурі компетентності особистості фахівця основним складником є творчий аспект самостійної діяльності.

Як бачимо, у 1971-1990рр. компетентним педагогом уважали творчу особистість, здатну самостійно обирати оптимальне рішення, ефективний шлях і вдалий метод, щоб виконувати завдання за будь-яких обставинах; володіти мобільністю знань і умінь, широкою ерудицією 3 певного предмета, критично мислити й бути креативною у професійній діяльності.

У праці Л. Петровської «Компетентність у спілкуванні» осмислено зміст зазначеної категорії як однієї з властивостей особистості, а також запропоновано конкретні спеціальні форми тренінгів для її формування [4].

Особливістю сучасного стану розроблення проблеми компетентнісного підходу в освітній галузі вважаємо визначення у документах і матеріалах ЮНЕСКО «ключових компетенцій». На думку більшості науковців, «компетентність» загалом і компетентність учителя - це здатність ефективно й творчо застосовувати знання та вміння в суб' єкт-суб' єктних ситуаціях. Компетентність - поняття, що логічно походить від ставлення до цінностей та від знань до умінь.

Подібним $є$ визначення, запропоноване працівниками Міжнародного департаменту стандартів для навчання, досягнення та освіти, котрі у визначенні змісту компетентності фахівця акцентують увагу на його спроможності кваліфіковано здійснювати діяльність, виконувати певне завдання чи роботу. При цьому до структури компетентності вони зараховують знання, вміння, навички і ставлення, що дають змогу особистості ефективно діяти або виконувати певні функції, спрямовані на досягнення сформульованих стандартів у професійній галузі або конкретній діяльності.

Н. Кузьміна у структурі професійно-педагогічної компетентності викладача виокремлює п'ять компонентів: спеціальну й професійну у межах навчальної дисципліни; методичну компетентність щодо способів формування знань і умінь учнів; соціально-психологічну компетентність у педагогічному спілкуванні; диференційнопсихологічну компетентність для формування позитивної навчальної мотивації учнів; аутопсихологічну компетентність щодо самоаналізу професійного росту [5, с. 90].

Аналізуючи визначення терміна «компетентність», запропоновані дослідниками, можемо стверджувати, що зазначена категорія $\epsilon$ цілісним комплексом професійних, соціальних й особистих знань, умінь і навичок самостійної професійної діяльності. Ураховуючи погляди науковців, сформулюємо робоче визначення поняття педагогічної категорії компетентності у площині фахової підготовки вчителя. На нашу думку, 
компетентність - це система властивостей особистості, що забезпечують ефективне, раціональне і творче використання знань і вмінь для самостійного розв 'язання завдань у міжособистісних стосунках в умовах професійних ситуацій та інтересах освітнього закладу.

\section{Література}

1. Овчарук О. В. Компетентності як ключ до оновлення змісту освіти / О. В. Овчарук // Стратегія реформування освіти в Україні: Рекомендації 3 освітньої політики. - К. : К.І.С., 2003. - 296 с. 2. Зимняя И. А. Ключевые компетенции как результативно-целевая основа компетентностного подхода в образовании/ И. А. Зимняя. - М. : Просвещение, 2004. - 180 с. 3. Равен Дж. Компетентность в современном обществе / Дж. Равен. - М. : Когнито-Центр, 2002.- 396 с. 4. Петровская Л. А. Компетентность в общении: социально-психологический тренинг. / Л. А. Петровская. - М. : МГУ, 1989. - 216 с. 5. Кузьмина Н. В. Профессионализм личности преподавателя и мастера производственного обучения / Н. В. Кузьмина. - М. : Просвещение, 1990. - 119 с.

УДК 372.011.31:373.2

Інна Кондратець

\section{РОЛЬ ІННОВАЦЙНИХ ТЕХНОЛОГІЙ У ПРОЦЕСІ ФОРМУВАННЯ РЕФЛЕКСИВНОЇ КУЛЬТУРИ ПЕДАГОГІВ ДОШКІЛЬНИХ НАВЧАЛЬНИХ ЗАКЛАДІВ}

Кондратець I. В. Роль інноваційних технологій у процесі формування рефлексивної культури педагогів дошкільних навчальних закладів.

Стаття присвячена проблемі формування рефлексивної культури у педагогів дошкільних навчальних закладів в умовах упровадження інноваційних технологій. Здійснено аналіз сучасного стану проблеми, конкретизовано зміст та методи формування рефлексії, запропоновано методи і прийоми, що сприяють розвиткові рефлексивних умінь і навичок.

Ключові слова: рефлексія, рефлексивна культура, рефлексивне середовище, рефлексивні уміння і навички, інноваційні технології.

Кондратец И. В. Роль инновационнных технологий в процессе формирования рефлексивной культуры педагогов дошкольных образовательных заведений.

Статья посвящена проблеме формирования рефлексивной культуры у педагогов дошкольных образовательных учреждений в условиях внедрения инновационных технологий. Осуществлён анализ современного состояния проблемы, конкретизирована суть и методы формирования рефлексии у педагогов, предложены методы и приёмы, которые способствуют эффективному развитию рефлексивных умений и навыков.

Ключевые слова: рефлексия, рефлексивная культура, рефлексивная среда, рефлексивные умения и навыки, инновационные технологии.

Kondratec I. V. The function of innovvative technologies in the process of forming of reflection culture of teachers of preschool educational establishments.

The article is devoted the problem of forming of reflection culture for the teachers of preschool educational establishments in the conditions of introduction of innovative technologies. The analysis of the modern state of problem is carried out, essence and methods 